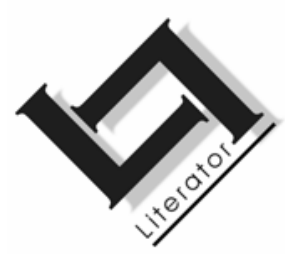

\title{
Classification of Setswana short stories
}

\author{
M.J. Mojalefa \& M.M. Makgato \\ Department of African Languages \\ University of Pretoria \\ PRETORIA \\ E-mail: Jerry.mojalefa@up.ac.za
}

\section{Abstract \\ Classification of Setswana short stories}

The aim of this article is to reclassify Setswana short stories according to their treatment of female characters. Critics such as Ranamane have classified Setswana literary works according to year of publication, without giving any valid reasons for this type of classification. This article, focusing on the development of the characterisation of women in Setswana short stories, classifies stories based on three periods, namely the phase of womanism, the experimental phase and the phase of feminism. In the phase of womanism, the outstanding features of characterisation of females include oppression and illtreatment, discrimination and segregation, ignorance, physical violence against females and limitation of the role of women to caring for the extended family. In the experimental phase, features include liberation of a female character, freedom of the whole society, agreement on marriage and working together as a team to solve the problems of society. The phase of feminism is identified by features of characterisation of females such as eradication of oppression, the fight for equality between women and men, removal of segregation and discrimination and also change across the whole of society.

\section{Opsomming}

\section{Klassifikasie van Setswana-kortverhale}

Die doel van hierdie artikel is om Setswanakortverhale te herklassifiseer volgens die aard van hulle vrouekarakters. Kritici soos Ranamane het letterkundige werke in Setswana volgens hulle publikasiedatum geklassifiseer sonder om geldige redes vir hierdie soort klassifikasie te gee. Hierdie artikel fokus op die ontwikkeling van karakterisering van vroue in Setswanakort- 
verhale. Hiervolgens word verhale geklassifiseer op grond van drie periodes, naamlik die fase van vrouebewussyn (womanism), die eksperimentele fase en die feministiese fase. In die fase van vrouebewussyn sluit die belangrikste kenmerke van vroulike karakterisering in: die onderdrukking en slegte behandeling, diskriminasie en segregasie, onkunde, fisiese geweld teen vroue, en die beperking van die vrou se rol tot die omsien na die uitgebreide gesin. Die kenmerke van die eksperimentele fase sluit in: die vrywording van 'n vroulike karakter, vryheid van die hele gemeenskap, ooreenkoms oor huwelike en mense wat as 'n span saamwerk om die probleme van die samelewing op te los. Die feministiese fase word gekenmerk deur eienskappe van vroulike karakterisering, soos die uitwissing van onderdrukking, die stryd om gelykheid tussen mans en vroue, afskaffing van segregasie en diskriminasie en ook die verandering in die hele gemeenskap.

\section{Introduction}

Ranamane (Geŕard et al., 1993:169-192), Sebate (1992:16) and Sikwane et al. (1984:8-21) classify Setswana literature according to historical periodisation. These critics emphasise this historical periodisation by using years of publication arranged according to decade. Though they sensitively utilise this approach, they unfortunately do not provide any valid reasons for this type of classification. This creates insurmountable problems for the classification of Setswana short stories, because, for example, authors of the same period may write about two or more different themes, which cannot be satisfactorily classified in one period. This problem of classification of Setswana short stories is related to thematic periodisation. While we recognise Ranamane's classification, the present article wishes to put forward an alternative classification of Setswana short stories according to their treatment of female characters into three phases, namely short stories of the phase of womanism, short stories of the experimental phase and short stories of the phase of feminism. However, before this can be done, it is essential to define the concept of classification in literature.

\section{Classification}

Janis (1977:121) discusses classification as separating objects which are different into groups. Lannon (1992:268-273) and Troyka (1993:99) support this argument by emphasising that those objects put in one group must have similar characteristics. Thus Meyer (1992:260-262) and Hodges, Horner and Webb (1998:19) say that when people or objects are classified, this clearly suggests that the 
author intends to expose a particular relationship that exists among those people or objects which could render assistance in arranging and comparing information already collected. Furthermore, Machiahan and Day (1984:156) illustrate that when people or objects are classified, it is not relationship only that is revealed, but also a certain arrangement by which those people or objects can be comprehended easily and in a lucid manner. The arrangement described by these critics includes the person who is classifying and the purpose for which he/she is doing it. Shipley (1970:60) connects classification with educational texts, stressing that when texts are classified, attention should be given to how those texts are the same and how they differ. Kgatla (2000:17) stresses that texts which are related form one group. In the investigation of this article, Setswana short stories will therefore be classified into three groups using a classification based on three pillars, namely of text structure, arrangement of events and type of text.

Some researchers have already attempted the classification of various Sepedi text types using various methods. Magapa (1997) sites Boileau and Narcejac's classification of detective texts into ten types and Groenewald (1993) classifies Sepedi detective stories into two main types, namely those that scare and those that bring comfort to the reader. When classifying Sepedi texts of love, Lebaka (1999) and Groenewald (1993) group them into two major classes, namely those that simply inform and those that entertain. Kgatla (2000) attempts a general classification of Sepedi short stories into three groups, namely moral/didactic short stories, experimental short stories and short stories of the phase of growth.

The classification of Setswana literary works by Ranamane poses problems in that it is based on thematic periodisation. It is therefore the aim of this article to classify selected Setswana short stories using a periodisation based on the treatment of women, which is divided into the phase of womanism, the phase of feminism and the experimental phase. Due to the length restriction of the article, quotes from the short stories are not made.

\section{Short stories from the phase of womanism}

According to Okonjo (Kolawole, 1997:24), womanism is a concept used in Africa to explain women's rights, more especially those of black women. Eisenstein (in Phillips, 1987:89) declares that women have their own rights. Hill-Collins (1990:39) and Ongundipe-Leslie (1994:229) argue that the rights of black and white women are not 
the same because most black women do not want to be like men and also are not oppositional to men, as some white women are.

Therefore, attention is directed at characteristics of womanism by which an African woman can be identified, namely oppression and ill-treatment of a female character, discrimination against and segregation of a female character, ignorance of a female character, physical violence used as punishment of a female character, inability of a female character to choose a partner and restriction of the role of a female character to taking care of the extended family.

These characteristics as they are related to the depiction of female characters are investigated in a few selected Setswana short stories. This will suggest that Setswana short story authors lack responsibility.

\subsection{Oppression and ill-treatment of a female character}

When discussing this aspect, Mawela (1994:18) says that, in Venda, when a girl reaches puberty she is no longer considered a child. She is immediately taken in for initiation where elderly women and older girls who have previously been initiated prepare the girl for womanhood. The girl is taught the tribal rules of etiquette and obedience, with the purpose of making her the submissive, tolerant and mature woman of tomorrow. Kolawole (1997:25) extends this opinion by indicating that African women are the product of multiple subjugation. Patriarchy, tradition, colonialism, neo-colonialism, racism and gender imperialism combine to act against the African women's self-assertion. Ramphele and Boonzaier (1988:156) support Kolawole, saying that there is a widespread ideology of male dominance among Africans which emphasises the idea that women pass through the control of different men throughout their lives. The short stories Mafaratlhatlha a botshelo and Sego sa metsi by Chikane provide illuminating examples.

Chikane (1987:6) indicates that, according to Setswana culture and morality in general, children must respect their parents. But in the short story Mafaratlhatlha a botshelo, this is not the case. This type of behaviour is undermined by the depiction of children disrespecting a female character because she is not their biological mother. These children continually compare the woman who is married to their father with their dead mother. As a result, it is clear that they love their real mother more than this woman. 
Chikane (1987:53) also illustrates another type of a female character when he emphasises how each family traditionally has its own rules governing its members. No family can allow an outsider to come and ruin its way of life. An intruder can interfere with matters of a particular family only to keep the peace. But in the short story Sego sa metsi, the mother-in-law to Naomi is an obstacle of peace because she demands money from her son which should be used to buy food for the whole family.

\subsection{Discrimination against and segregation of a female character}

Marchand and Parpart (1995:139) say that in many changes and policy shifts, African women have not been given adequate attention as major producers of labour and national wealth. For a long time, research about African women has constituted a marginalised discourse largely undertaken by social anthropologists who relegate women to the spheres of childbearing and small-scale economic production. Sebakwane (1993:31) supports the above theorists, stating that within the Pedi family, boys and girls are socialised into specific gender roles. Girls learn domestic chores through observation, imitation and repetition of the behaviour of their elders, performing tasks such as fetching water, grinding corn, sweeping the courtyard, gathering wood and assisting in agricultural activities. On the other hand, boys are expected to learn the skills of tending livestock, herding sheep, goats and later cattle. Pedi boys and girls are encouraged to accept gender role differences as natural and normal. Mtuze (1990:5) points out that the value system of African people like the Pedi and Tswana have been so affected that the terms ubufazi (womanhood) and umfazi (women) have come to have negative connotations. Umafazi implies a creature that is subservient and submissive with very little or no ability to think widely.

In Khutsana Ntsime (Magoleng \& Ntsime, 1972:53) portrays discrimination against and segregation of a female character, suggesting that she should not be regarded as a human being but that the best thing for her is instead to become a slave for other people, a slave who has to obey the rules of her boss. In this way, the rights of the female character are infringed because she is not considered as a person. She is regarded as a tool to be used by any male person at any time. Similarly, in the short story MmaModiegi, Sikwane (1987: 32) also discriminates against and segregates a female character by 
regarding her as an instrument to be used by the male character. In other words, Ntsime and Sikwane ridicule their female characters.

\subsection{Ignorance of a female character}

When speaking of ignorance, Miller (1979:11) argues that subordinates often know more about the dominants than they know about themselves; this is logical, for if a large part of a woman's fate depends on accommodating and pleasing these dominant people, then she will concentrate on them. This simply means that women, when subordinate to men, tend to forget about themselves and care much more about their men.

This is illustrated in the short stories O nkut/we by Malope, Seteropo ke sa gago by Shole and Sego sa metsi by Chikane in which a female character is portrayed as ignorant. In $O$ nkutlwe a female character, Kedisaletse, allows a male character, Pekwa, to fill in the papers for her when she buys a car; instead of writing Kedisaletse's particulars he writes his own. Similarly, in Seteropo ke sa gago the female character, Sedie, is reprimanded when she reports that male visitors came looking for her husband during the day. As a result she decides to lie to her husband in future, saying that no one visits during the day when her husband is at work. This indicates ignorance because Sedie does not see that she is oppressed by fear, and that this is why she decides to keep quiet. In Sego sa metsi Naomi is not welcomed into her new family by her mother-inlaw. Later, when her husband is away, Naomi is ill-treated and does not tell her husband because she is afraid of her in-laws.

In these short stories, Malope (1982:53), Shole (1985:80) and Chikane (1987:53) reveal a particular oppression which is subtle but very powerful, namely that of ignorance. These authors sometimes reveal this by suggesting that female characters need other people to do jobs for them which an informed person would be able to do herself. Also, this type of ignorance is sometimes rendered by the fact that even when female characters can force their voices into male discourse they will not be heard because of their low status. They therefore become voiceless to avoid disappointment.

\subsection{Physical violence used to punish female characters}

Cock (1984:181) argues that the structures of inequality of the relationship between employer and domestic worker vary from kindly paternalism to extreme brutality. Both sets of attitudes and treatment involve a denial of human dignity. The most typical viewpoint is that 
the servants are like children and should be treated with kindness and firmness. The child-like qualities most commonly attributed to them were irresponsibility, secretiveness, an inability to work without supervision and frivolity. In addition, they are generally perceived to be lazy and dishonest (at least inclined to petty theft), often stupid, lacking in initiative, ungrateful and indubitably inferior. A similar complex of expectations becomes attached to women, suggest Bianchi and Ruether (1967:7-20), when women are seen as created to be men's helpmates, to serve men as mothers and sex objects. Emphasis is placed on quotations from the short stories Seteropo ke sa gago by Shole and Khutsana and Lerato le e seng lona by Ntsime (Magoleng \& Ntsime, 1972).

In these short stories, Shole (1985:88) and Ntsime (Magoleng \& Ntsime, 1972:4 \& 50) stress that a female character is regarded as a pet or a child with inferior intelligence, who should be beaten when she has done something wrong. In these three short stories female characters are beaten by male characters who feel the women have done wrong.

\subsection{Inability of a female character to choose a partner}

Stayt (1968:145) suggests that in the womanist construct, as a rule, marriage is arranged between parents and is accepted by the young without demur, although, if the girl expresses a strong dislike for the chosen man, her feelings are sometimes considered and new arrangements can be made, subject to the consent of the man to whom the girl is betrothed. Dlamini (1995:16) adds that this practice among traditional families is carried out because it is believed that the girl as a minor can be given to any man who has enough cattle for lobola. Two short stories emphasise this issue, namely MmaModiegi by Sikwane and Khutsana by Ntsime. (Magoleng \& Ntsime, 1972). Only a few examples are investigated from each of these short stories.

MmaModiegi is shown to be against the relationship of her daughter, Modiegi, and Tshipa, Dupelelang's son. Sikwane (1987:32) illustrates how MmaModiegi chooses a partner for her daughter because she does not want Tshipa, a poor person, to be her son-in-law. In older Setswana culture, it is acceptable for a parent to choose a partner for his/her child, but Sikwane stresses that this still happens in modern society, since this short story was written in 1987. In the period in which this short story was written, the phase of womanism and the phase of feminism are thus shown to be in contradiction. 
Similarly, in the short story Khutsana, Ntsime (Magoleng \& Ntsime, 1972:58) describes how parents encourage their son to marry the girl they like. They choose a wife for their son so that she can also look after them when they are old, which is unacceptable in the context of feminism. This, however, proves that in Setswana culture a woman is not married to her husband only but also to the extended family. Ntsime intertwines the phase of womanism and the phase of feminism, because although, according to Setswana culture, a man who marries the king's daughter becomes the prince, in this short story it is different.

\subsection{Restriction of the role of a female character to taking care of her extended family}

As England (1993:38) puts it, women's status as unskilled, not unionised and underpaid workers both reflects and promotes their continued restriction to being caretakers in the household. The only difference between women's paid and unpaid labour is that one brings direct returns in the form of a wage and the other does not. Both types of labour are actually the same in that they both help to support capitalism and patriarchy. Women's role as caretakers in the household also carries over into the labour market where they are considered as helpmates, working as children's teachers and service workers. As a result, they are rewarded less than men because of their presumed commitment to home and hearth. This is the issue that compels Mrwebi (1996:94) to reiterate that because women are increasingly working outside the home, they need partners who are willing to share some of the domestic burdens that traditionally fall on women. She declares that the role of the man in raising the family is as important as the woman's role. The woman does not mind doing housework alone, but the man must realise that it is the responsibility of both parties. Goosen (1993:51) states that the kitchen is always associated with a standard home and more often than not with a "standard woman". A number of common colloquial constructions serve as sexist insults focusing specially on the apparently close bond which exists between a woman and her kitchen. These sexist insults are specifically designed to ensure or at least to attempt to ensure that women will not stray from their traditional, stereotype which demands that they will be homemakers, comfortable home bodies, cleaners who breed, obey, serve and satisfy their masters. This means clearly that a woman belongs in the kitchen, preferably barefooted and pregnant. A few examples of this kind of attitude come from the short stories Mafaratlhatlha a botshelo and Sego sa metsi by Chikane. In these stories the author 
(Chikane, 1987:56-57) discloses that a female character is not married for the good of the man but also for that of other members of the family. This is why she stays with the in-laws for a couple of years to prove herself as a "real woman", because she is supposed to do all the work at home.

This examination of details from the short stories Mafaratlhat/ha a botshelo, Sego sa metsi, MmaModiegi, Seteropo ke sa gago, O nkutlwe, Lerato le e seng lona and Khutsana has shown how some Setswana short story authors depict female characters in the traditional womanist manner. Even if they write about female characters of the phase of feminism, they still emphasise that these female characters belong to patriarchal-traditional structures. This vividly conveys the fact that the lives of female characters are static even if the conditions under which they live change. This implies that female characters are men's property and should always obey men's rules in all spheres of life. This depiction of female characters by Setswana short story authors cause problems related to the real lives of women. However, this traditional oppressive depiction of female characters by Setswana short story authors can be expected to move with the time, so that when social life changes, the description of female characters should also change. This leads to the concept of the phase of feminism, both in life and in literature.

\section{Short stories on the phase of feminism}

The theory of feminism will not be dealt with in full because its tenets are widely known. However, some important points will be briefly discussed. Ashworth (1995:1-2) describes feminism as a way of life characterised by understanding, friendship, love, communication and solidarity among women. Greene and Kahn (1996:229) state that feminism aims at ending oppression and discrimination against women in society. This oppression, according to Jefferson and Robey (1986:204), Achifusi (1987:40) and Modupe-Kolawole (1997: 2 ) is caused by men who shape the world to suit their own domination. This is why Walker (in Modupe-Kolawole, 1997:2) mentions that feminism is the freedom of women from the dominance of manpower. Phillips (1987:68) and Masuku (1997:16) point out that feminism is related to democracy because women associated with it are liberated, fight for their rights and are cunning, and also do not hesitate to go out of their way and do everything necessary to achieve their projected goals. In other words, they do not want to have anything to do with men at all because they believe that men have always taken care of themselves. This analysis will 
be based on the following characteristics relevant to this examination, namely attempts to eradicate oppression of a female character, to fight for equality between a female and a male in all spheres of life, to remove segregation of and discrimination against a female character and to change the whole society. The short stories to be interrogated using the phase of feminism are MmaModiegi and Tlogela ngwanake by Sikwane, Seteropo ke sa gago by Shole, Sego sa metsi by Chikane, O nkutlwe and Bodiba jo bo jeleng ngwana a mmaago ... by Malope.

\subsection{To eradicate oppression of a female character}

Recent decades have seen international efforts to emancipate women. The United Nations organised a series of international conferences that have focused on the status of women, such as The United Nations World Conference on Women held in September 1995 in Beijing. Women from all over the world met to devise strategies to deal with oppression and the many obstacles that prevent women's empowerment. As peace, equality and development were the themes of the Conference, delegates from 180 countries used the opportunity to put aside their differences, and concentrate on practical ways in which women's full and equal participation in development, politics and decision-making could be realised. Women focused on ways in which they can cooperate internationally to achieve world peace (Beijing Conference, 1995:iiiiv, 2). This conference is an example of feminist activism by women. Similar activism can be traced in the short stories Seteropo ke sa gago by Shole and O nkut/we by Malope.

Shole (1985:80) and Malope (1982:52) are both male authors of Setswana short stories, who depicts female characters who are strong. The relationship of these female characters with their husbands and also the extended family causes hostility among them. The female characters stand up for themselves because they are tired of male domination and of being imprisoned. They feel that they have a right to contribute to family life and to compete with their male counterparts in all spheres of life. These male Setswana short story authors describe female characters as civilised beings who fight against all odds to get their rights and freedom back.

\subsection{To fight for equality between a female and a male in all spheres of life}

Kolawole (1997:13) figuratively explores equality by saying that a woman needs a home in which everyone has a room of her own, but 
also one in which the walls are thin enough to permit a conversation. Ferrante (1975:8) compares disempowerment of women with the women's role in the Middle Ages, which involved activity in various areas of public life. There are numerous examples of women who acted as regents for their husbands or sons, who led the defence of their towns, who conspired for power against the rightful heirs, or who mediated between warring parties. Their exploits can be read about in contemporary histories and chronicles.

Such equality in public life is in the feminist view accompanied by freedom of choice and equality in private life also. Short stories portraying this view include Tlogela ngwanake by Sikwane and Bodiba jo bo jeleng ngwana a mmaago ... by Malope.

Sikwane (1987:21) and Malope (1982:8) mention that, according to Setswana culture, a man is the head and the leader of his family. He is the one who, according to societal custom, has the right to beat a woman when she has done something wrong, and he only is allowed to instigate a sexual relationship. However, in the first short story, a woman and her son beat up a man, while in the second short story, a woman asks a man to let her become his concubine. This contradicts the moves of traditional Setswana culture. The two Setswana short story authors emphasise equality between men and women. This simply means that anything that a man can do, a woman can also do because they are both human beings of equal status.

\subsection{To remove segregation of and discrimination against a female character}

Ryan (1988:21) believes that l'écriture feminine is a statement about new language; it is not intended to be a solution to woman's oppression per se but a means whereby women can challenge the existing linguistic structures which are dominant, controlling and male-oriented. Modupe-Kolawole (1997:30) extends this opinion when she says that African women yearn for a society in which they can assert their innate resourcefulness by rejecting the fetters of tradition and any aspects of socialisation that puts them at a disadvantage. These women seek to convince men that they can be productive in the home and outside the home by their resilience and dynamic drive in economic areas. This is an indication that women are interested in re-humanising the world by enhancing their roles positively, even considering themselves more suitable for certain roles than men. This characteristic is examined in the short story MmaModiegi by Sikwane. 
Sikwane (1987:34) shows the eradication of segregation and discrimination among people. He explains that, if a girl and a boy are in love, parents should not interfere, for example by investigating their family backgrounds, because the couple know what they want in life and will achieve their projected goals. What is implied by this short story is that in a relationship there should be no segregation or discrimination. In other words, the newly married couples must have their own goals clearly defined so that they can fight to accomplish what they need in life.

\subsection{To change the whole society}

Modupe-Kolawole (1997:22) discusses how, since the pre-colonial period, African women have been involved in fighting for the rights of their societies. African women seek an inclusive basis for action across class and ethnic lines. Ogundipe-Leslie (1994:64) mentions that the refusal by many African women to align themselves with the movement that intends changing the whole society is because of the successful intimidation of African women by men on the issue of women's liberation. Male ridicule, aggression and backlash made many women apologetic and have given feminism a bad name. However, feminism is the business of both women and men and all men need to be progressive feminists, committed to a socially just society. There is a need to liberate the whole society from dehumanisation. This vividly says that the whole social system should be changed because men are not the enemy, which is the subordination and oppression of women. The short stories that deal with this aspect are Tlogela ngwanake by Sikwane, Seteropo ke sa gago by Shole and Sego sa metsi by Chikane.

Sikwane (1987:21), Shole (1985:2) and Chikane (1987:49) show that female characters should be liberated like any other person. The women are tired of dominating masters. These Setswana short story authors do not simply admire isolated female characters who are liberated, but also suggest that people in the wider society should also enjoy this freedom. The authors link feminism with women who are changing with time. In this phase, women need equality with men and among themselves, in order to be selfassertive and very confident to stand by themselves without the support of men.

These Setswana short story authors do not take into account all the rights accorded to women in the Constitution. What these short story authors portray is thus not in complete accordance with feminism. Equality between men and women is not achieved in all spheres of 
life because some short story authors still depict female characters struggling with some problems. These problems form the focus of stories of the phase of mixed characteristics, the experimental phase, seen as the phase of womanism which develops into the phase of feminism.

\section{Short stories of the experimental phase}

The experimental phase is the phase between the phase of womanism and the phase of feminism. It is the phase where women come to the realisation that they have the same rights as men, and that they are now challenging patriarchy and are insistent about the need to restructure existing laws, both common and customary, as these laws to a large extent legitimise and reinforce women's economic disempowerment. Thus, according to Nzomo (1995:132), in this sphere African women, regardless of their class or ethnic background, realise their subordinate status and the opportunity presented by multiparty democracy to change their status. For examples, Kenyan women insist that universally accepted democratic ideals be adhered to in practice, which includes ensuring equality of women and men, and making women equal and effective participants at all levels of decision-making. Njoku (1980:45) gives another example from Nigeria, where in 1929 a riot by local women led to many reforms in native courts, which opened the door to indirect rule.

Setswana short story authors writing in the phase of experimentation intermingle both the phase of womanism and the phase of feminism. Their stories thus show features that appear in both the phase of womanism and the phase of feminism. Characteristics which are considered in the experimental phase are the liberation of a female character, freedom of the whole society, agreement on marriage and working together as a team to solve the problems facing society.

\subsection{The liberation of a female character}

Winnie Mandela, cited by Goosen (1993:57), says that black women in South Africa must voice their growing dissent from the cultural traditions which bind them to their past. She stresses that, looking at our struggle in this country, the black woman has had to struggle a great deal, not only from a political angle. She has had to fight male domination in a much more complex sense. One example is the difficulty black women experience as a politician in a culture that traditionally sees a woman's place as in the home. Of course many cultures struggle with these issues, but in South African tribal law, a 
woman is a permanent minor by law. Thus, for a woman to emerge as an individual and as a politician is certainly not easy (Mandela, 1985:83-84). Njoku (1980:32) discusses economic liberation in African marketplaces, when he declares women outnumber males and compete successfully with them in all areas of retail goods, particularly in consumer-goods items. Those who live in the rural areas buy from the local periodic markets and then retail the commodities in the local daily markets. Despite this, African women lack right to own a land, or to farm their husband's plot of land, as well as the absolute right to sell and buy in the marketplace without the permission of their husbands. The struggle against this kind of disempowerment is seen in short stories of the experimental phase.

This issue is examined in the short story $O$ nkut/we by Malope, in which the author intertwines the phase of womanism and the phase of feminism. Female characters, according to both these approaches, need to be liberated. This liberation is achieved differently in the two approaches. Women in the phase of womanism explain that, though they need freedom, they will have to accommodate men in an agreed concerted effort, because men are the heads and leaders of families. This implies that womanism is not antagonistic to African men though it wants to challenge them to realise and change certain salient patriarchal features which oppress women. According to womanism, for example, there are certain household tasks which women cannot do because they need men's efforts. Feminism, on the other hand, says women need all the rights prescribed in the Constitution. Women must not be imprisoned again. This approach differs from that of womanism because it says women must compete with men in all spheres of life and should be under no one's supervision. Feminist women believe that what men can achieve, they can as well. In other words, feminist women refuse to put themselves down as compared to men.

Malope (1982:47-48) describes a female character by the name of Kedisaletse as somebody who conforms to feminism. What she says is in accordance with feminism because she fights for her rights to contribute to her family just like her husband. She agrees with feminism because she wishes that female characters should have the same human rights as other people. Malope (1982:53) contrasts this with the character called Pekwa, who allows the infringement of her rights. This female character explains that there are jobs in the household which should be executed by males. Kedisaletse admits this, while still considering herself a free woman because she is not affected in any way. She does not realise, 
Malope says, that by so doing she permits her rights to be violated by other people. Therefore, this gives a vivid portrayal of the problems facing a female character who agrees with today's freedom while still acknowledging cultural tradition.

\subsection{Freedom of the whole society}

Njoku (1980:7) believes that women do not only want to free themselves but also the whole society, by saying that whatever profits women have realised after the day's market activities are often shared with their husbands and children. Furthermore, the theorist indicates that African women in the late twentieth century began to encourage their daughters to go to school and get a proper education. Frequently it was their mothers who became the mediating forces between the old world's cultural attitudes of the male population towards educating women and the new educational opportunities opening up for women which they wanted their daughters to take advantage of. Marchand and Parpart (1995:132) are of the same opinion, arguing that women more than any other interest group have come out very strongly demanding that their voices be heard and that their gender-based interests be included and mainstreamed in the new democratisation process. Women activists and scholars have, therefore, embarked on massive campaigns of political mobilisation, concretisation and sensitisation of other women (and men) on the links between gender equity, democracy and development. In other words, the struggle against gender subordination is linked with the struggle against oppression based on nationality, class and identity.

However, in many traditional societies a female is oppressed from childhood to womanhood. According to Setswana culture, before a girl can get married, she is first sent to initiation school to be taught how to care for her husband. There, the girl will be instructed on how to cope with family problems, to be submissive and very cold when her husband speaks and to look upon her husband as a hero because he generates the income. These teachings become the beginning of oppression of the female, because they imply that the girl has no right to voice her feelings. Her role is to passively accept the instructions as they come from the older women. Thus, women in the phase of womanism and the phase of feminism who wish to be liberated from this oppression advocate change involving the whole society. They believe that every person should have an opportunity to study, to be involved in politics, to be employed anywhere he/she wishes, to have leisure time anywhere, etcetera. 
These women see collective grouping and positive bonding as necessary to fight against anything that could be an obstacle in their mission.

Malope (1982:50) in his short story O nkut/we implies that Kedisaletse, a female character, again permits her rights to be violated by asking assistance from Tholo, her brother in-law, asking him to take over the responsibilities of his deceased brother, Mofeti Matlapeng. However, this violation is justified because she does not want to free herself alone but also to liberate her two sons, together with Tholo. This idea, to free the whole society, is common to both feminism and womanism.

\subsection{Agreement on marriage}

After the day's work in the market, African women traditionally return home to prepare food for their husbands who will be sitting outside their huts waiting to be served by their wives. However, modern educated African women are going through cultural changes. The influence of education as well as contact with foreign women has helped to change the status of women tremendously (Njoku, 1980:33). Two types of marriages are now common in African societies. Both the church and the courthouse wedding are contracted only after the completion of the traditional ceremonies. Dlamini (1995:18) says many African women nowadays can even choose the type of marriage they want. However, this does not liberate them from some of the traditional practices. They still have to hide their feelings about their in-laws. They have to respect them in all costs. Even in the case of polygamy, she is expected to accept it as a customary right of the man. Mbiti (1975:133) demonstrates that, for African people, marriage is the focus of existence. It is the point where all the members of a given community meet: the departed, the living and those yet to be seen. All the dimensions of time meet here and the whole drama of history is repeated, renewed and revitalised. It is further indicated that marriage therefore, is a duty, a requirement from the corporate society, and a rhythm of life in which everyone must participate.

Women in the phase of womanism and also in the phase of feminism conform on the matter concerning marriage of a female character. When a woman is a grown-up, she has to have her own family. Womanism differs in upholding the custom of lobola so that the rights of a woman are properly respected. 
Malope (1982:52) shows how Kedisaletse believes that her husband's property is part of her property. No outsider can tell her what to do with the property because she and her husband, Mofeti Matlapeng, are married in community of property. This suggests that her husband's possessions are hers and hers are her husband's.

\subsection{Working together as a team to resolve the problems of the society}

Modupe-Kolawole (1997:15) maintains that there is a type of feminism which sees all problems in society as caused by men. She says that this is mistaken, since men are not the creators of the problems of the society. She reiterates that men and women have to work together to solve these problems. Mrwebi (1996:94) says that women are voicing their cry that men need to appreciate women's talents, and must not feel threatened by the new way of life; rather, they must encourage and support it. This indicates that women seek an inclusive basis for action across class and ethnic lines. Dlamini (1995:63) says that women in the African context are not fighting with African men but challenging them to be aware of certain salient aspects of women's subjugation which differ from the oppression of African men.

Women in the phase of womanism and the phase of feminism realise that to work together as a group is highly important in solving the problems affecting society. Men and women should come together to better the economy of their families. Malope (1982:46) maintains that work is not only restricted to men but that women should also work for themselves. This is the main thrust of feminism. In the short story Le fa o ka e buela lengopeng .... Malope (1982:18) creates a female character, Malešwane, who accepts that according to Setswana culture, some jobs are meant for male characters, such as to make a coffin, hire a tent or buy a cow to be slaughtered and a blanket for the deceased. On the other hand, however, she also believes that, when a death occurs in a particular family, the women also perform certain jobs such as to assist with cooking food and to stay at home to welcome visitors. In this case, this author mixes both the phase of womanism and the phase of feminism. Women of this type can be called women of the experimental phase. This is illustrated by the following sketch: 


$\begin{array}{lll}\text { Phase of } & \text { Experimental } & \text { Phase of } \\ \text { womanism } & \text { phase } & \text { feminism }\end{array}$

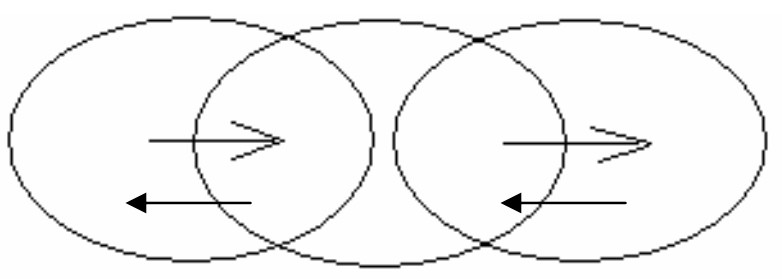

a $\quad$ b $\quad c$

If group (a) is examined, the phase of womanism is still pure. It has not yet been affected by other cultures. In group (b), which is the experimental phase, there is a change because there is a mixture of the phase of womanism and the phase of feminism. These stories involve events both of the phase of womanism and the phase of feminism. The female character in the experimental phase does not know where she belongs, either in the phase of womanism or the phase of feminism, and the events of her life are changing with the time and becoming modernised. In group (c), which is the phase of feminism, there are more changing events and very few issues remaining related to womanism.

\section{Conclusion}

Traditionally, Setswana short story authors are influenced by the manner in which they live as well as the events that happen to them. They write according to their ways of life. When life changes, people change too. This is why Setswana short story authors are forced to change because they participate in the mixing of different cultures which is influencing Setswana culture, in the 21st century. People change and move into the experimental phase, leaving behind other cultural features and then again move into the phase of feminism.

Because of changes in life, culture also changes. Tomorrow's life will also have to change. In the future Setswana short story authors will portray female characters in a way different to that of the present-day description. This is why the selected Setswana short stories can successfully be classified when based on these three phases, namely the phase of womanism, the phase of feminism and the experimental phase. In the phase of womanism, oppressive cul- 
tural beliefs through which female characters are depicted move from one generation to the next. Female characters end up being despised and there is little real information related to female characters available in literature. This distorted view which undermines female characters is still utilised by novice Setswana short story authors but then they stand in conflict with the Constitution of South Africa. It is as though Setswana short story authors still believe that female characters are traditional women under the patriarchal dominance who do not change with time, because the arrangement of the content in their short stories is determined by traditional Setswana culture.

As there are few reliable sources describing the real lives of women in the phase of womanism, one cannot guess the extent of the distortion present in Setswana short stories. Widespread changes in life have forced many Setswana short story authors to attempt to write about female characters from the feminist point of view, and they employ in their short stories, though often haphazardly, elements of feminism. This article has shown that many Setswana short story authors intermingle womanism and feminism. They describe female characters with equal rights as men, but also portray them allowing men to violate these rights. Therefore, these Setswana short story authors show the phase of womanism and the phase of feminism in contradiction. Perhaps because Setswana culture has not yet fully outgrown the oppression of women, this is the reason why no Setswana short stories yet reflect purely feminist thinking.

This method of classifying Setswana short stories is useful because it leaves space for further development. As Setswana writing develops with its shaping culture, this classification can expand to whatever future phase we find to harmonise feminism and traditional culture, to the enrichment of both women and men.

\section{List of references}

ACHIFUSI, G. 1987. Feminist inclination of Flora Nwapa: the feminist novel in Africa. London: James Curry. (Women in African literature today.)

ASHWORTH, G. 1995. A diploma of the oppressed: new directions in international feminism. Book 1. London: Zed Books.

BEIJING CONFERENCE. 1995. Its implications and challenges for South African women. Siren news, 4(1).

BIANCHI, E.C. \& RUETHER, R. 1967. From machismo to mutuality. New York: Paulist.

CHIKANE, O.K. 1987. Mafaratlhatlha. Mmabatho: Maikatlapelo.

COCK, J. 1984. Maids and madams. Johannesburg: Ravan. 
DLAMINI, S.R. 1995. Voicing their perceptions: a review of Swazi women folksong. Pretoria: Unisa. (M.A. thesis.)

ENGLAND, P. 1993. Theory on gender: feminism on theory. New York: De Gruyter.

FERRANTE, J.M. 1975. Women as image in Medieval literature. New York: Columbia University Press.

GERARD, A.S. 1993. Comparative literature and African literatures. Ed. by C.F. Swanepoel. Pretoria: Via Afrika.

GOOSEN, J. 1993. The kitchen as a battlefield: with special reference to the award winning play, Kitchen blues. Journal of literary studies, 91(1):51.

GREENE, G. \& KAHN, C. 1996. Making a difference: a feminist literary criticism. London: Methuen.

GROENEWALD, P.S. 1993. Thutadingwalo ya Sesotho sa Leboa. Pretoria: University of Pretoria.

HILL-COLLINS, P. 1990. Black feminist thought: the knowledge, consciousness and politics of empowerment. New York: Routledge.

HODGES, J.C., HORNER, W.B., \& WEBB, S.S. 1998. Hodge's harbrace handbook. New York: Harcourt Brace.

JANIS, J.H. 1977. College writing: a rhetoric and handbook. New York: Macmillan.

JEFFERSON, A. \& ROBEY, D. 1986. Modern literary theory: a comparative introduction. London: Batsford.

KGATLA, P.M. 2000. Kgolo, Tšwelopele le Katlego ya Kanegelokopana ya Sepedi: 1951-1999. Pretoria: University of Pretoria. (D.Litt. dissertation.)

KOLAWOLE, M.E. 1997. Womanism and African consciousness. Trenton: African World Press.

LANNON, J.M. 1992. The writing proccess: a concise rhetoric. Dartmouth: Harper Collins.

LEBAKA, K.J. 1999. Megokgo ya Lethabo: Kanegelo ya Lerato ya Sepedi. Pretoria: University of Pretoria. (M.A. thesis.)

MACHIAHAN, K. \& DAY, S. 1984. The writer's rhetoric and handbook. San Francisco: McGraw-Hill.

MAGAPA, N.I. 1997. Papetšo ya Dikanegelokopana tša Kebioa. Pretoria: University of Pretoria.

MAGOLENG, B.D. \& NTSIME, J.M. 1972. Mpolelele dilo. Kaapstad: Via Afrika.

MALOPE, R.M. 1982. Mmualebe. Mamelodi: Vista University.

MARCHAND, M. \& PARPART, J.L. 1995. Feminism/postmodernism development. London: Routledge.

MASUKU, M.J. 1997. Images of women in some of Zulu literary works: a feminist critique. Pretoria: Unisa. (M.A. thesis.)

MAWELA, F. 1994. The depiction of women characters in Venda novels. Pretoria: Unisa.

MBITI, J.S. 1975. African religious and philosophy. London: Heinemann.

MEYER, A. 1992. Writing with confidence. New York: Harper Collins.

MILLER, J.B. 1979. Towards a new psychology of women. Harmondsworth: Penguin.

MRWEBI, N. 1996. Women of the nineties: what they expect from their relationships with men. Ebony, South Africa, June 96:96.

MTUZE, P.T. 1990. A feministic critique of the images of women in prose works of selected Xhosa writers (1909-1980). Cape Town: University of Cape Town. (M.A. thesis.) 
NJOKU, J.E.E. 1980. The world of African women. Metuchen: Scarecrow.

NZOMO, M. 1995. Women and democratization struggle in South Africa: what relevance to postmodernism discourse? (In Marchand, J.H. \& Parpart, J.L., eds. Feminism/postmodernism. London: Routledge. p. 131-141.)

OGUNDIPE-LESLIE, M. 1994. Recreating ourselves: African women and critical transformation. Trenton: Africa World Press.

PHILLIPS, A. 1987. Feminism and equality. Oxford: Blackwell.

RAMPHELE, M. \& BOONZAIER, E. 1988. The position of African women: race and gender in South Africa. Cape Town: David Phillip.

RYAN, P. 1988. What do women want? A psycho-literary investigation to the quest for fulfillment in recent writing by women (1965-1985). Pretoria: Unisa.

SEBAKWANE, S. 1994. Pedi women and colonial legacies. Matlhasedi, 13(3):10-14.

SEBATE, P.M. 1992. The Tswana short story: from D.B. Magoleng to O.K. Bogatsu. Pretoria: University of Pretoria. (D.Litt. thesis.)

SHIPLEY, J.T. 1970. Dictionary of World Literary Terms: forms, techniques. London: Allen \& Urwin.

SHOLE, S.J. 1985. O Foo ke Fano. Pretoria: De Jager.

SIKWANE, L.Z. 1987. Iphimole Dikeledi. Mabopane: Anderson.

SIKWANE, L.Z., MOTHOAGE, M.K. \& SEBATE, P.M. 1984. Tswana study guide for TWA 100-8. Pretoria: University of Pretoria. (Dikwalo; Porouse, Poko, Terama.)

STAYT, H.A. 1968. The Bavenda. London: Frank Cass.

TROYKA, L.Q. 1993. Handbook for writers. Englewood Cliffs: Prentice Hall.

\section{Key concepts:}

classification

phase: experimental

phase: feminism

phase: womanism

Setswana short stories

\section{Kernbegrippe:}

fase: eksperimentering

fase: feminisme

fase: vrouebewussyn

klassifikasie

Setswana-kortverhale 
